RYSZARD DANIEL GOLIANEK

UNIWERSYTET IM. ADAMA MICKIEWICZA W POZNANIU

AKADEMIA MUZYCZNA IM. GRAŻYNY I KIEJSTUTA BACEWICZÓW W ŁODZI

\title{
PROBLEMATYKA POLSKA W XX-WIECZNYCH OPERETKACH NIEMIECKICH
}

dentrami niemieckojęzycznej operetki stały się pod koniec XIX w. Berlin i Wieprowincję Niemiec i Austrii, jak i do krajów wcielonych lub zależnych, takich jak Czechy, Węgry czy Polska. Szeroka obecność w niemieckiej operetce ${ }^{\mathrm{I}}$ postaci i wątków wiążących się ze społecznościami narodowymi i etnicznymi świadczy o postrzeganiu ich znaczącej roli i miejsca w kulturze Niemiec i Austrii, jak i o jednoczesnym identyfikowaniu kultur tych społeczności jako odrębnych i atrakcyjnych².

Wśród bogatego kręgu repertuarowego niemieckiej operetki, zwłaszcza na początku XX w., dość znaczący udział przypada dziełom, w których fabule zawarte są nawiązania do tematyki polskiej bądź wprowadzani są polscy bohaterowie. Dominującym - choć nie jedynym - sposobem prezentacji polskiego środowiska narodowe-

I Dla uproszczenia wywodu używam pojęcia „operetka niemiecka” w znaczeniu dzieł operetkowych w języku niemieckim tworzonych w Niemczech, Austrii oraz w krajach znajdujących się pod ich władzą i zwierzchnictwem. Mimo pewnego braku precyzji, termin taki funkcjonuje w literaturze przedmiotu, podobnie jak określenia odnoszące się do innych dzieł wokalno-instrumentalnych, takich jak np. opera włoska i niemiecka w twórczości Mozarta, Haydna itp.

2 Literatura muzykologiczna poświęcona gatunkowi operetki jest stosunkowo ograniczona. Szerszy kontekst porównawczy dotyczący operetki, w którym dochodzą do głosu także kwestie społeczne i polityczne związane z tym gatunkiem, zawierają następujące prace: Moritz Csáky, Ideologie der Operette und Wiener Moderne: Ein kulturhistorischer Essay zur österreichischen Identität, Wien I996; Camille Crittenden, Johann Strauss and Vienna: Operetta and the politics of popular culture, Cambridge 200o; Warum es der Operette so schlecht geht: Ideologische Debatten um das musikalische Unterhaltungstheater (I880-I9I6), red. Marion Linhardt, Wien 200I; Richard Traubner, Operetta: A theatrical history, New York 2003; Volker Klotz, Operette: Porträt und Handbuch einer unerhörten Kunst, Kassel ${ }^{2} 2004$. Najnowsze prace poświęcone problematyce niemieckojęzycznej operetki to: Kunst der Oberfläche: Operette zwischen Bravour und Banalität, red. Bettina Brandl-Risi, Clemens Risi, Leipzig 2015; Albert Gier, Wär'es auch nichts als ein Augenblick: Poetik und Dramaturgie der komischen Operette, Bamberg 20I4; Heike Quissek, Das deutschsprachige Operettenlibretto: Figuren, Stoffe, Dramaturgie, Stuttgart 2012. 
go staje się jego konfrontacja z przedstawicielami społeczności zaborców (Niemców, Austriaków i Rosjan), a wynikające z takiej konfrontacji różnice zachowań i cech osobowości bohaterów niejednokrotnie generują główne konflikty dramatyczne w akcji operetek. Sposób kreacji bohaterów oraz ich charakterystyka stają się jednocześnie przejawami swoistych stereotypów dotyczących poszczególnych nacji, zaś moralna ocena postępowania postaci prowadzi często do uogólnień odnoszących się do zbiorowości czy zgoła całych narodów. Z tego względu niemieckie operetki o tematyce polskiej zasługują na baczniejszą uwagę, są one bowiem ważnym materiałem badawczym, którego analiza pozwala zrekonstruować ówczesne wyobrażenia Niemców i Austriaków o Polakach, a także zmierzyć temperaturę wzajemnych stosunków wspólnie egzystujących nacji ${ }^{3}$. Ten najważniejszy aspekt operetki został w poszczególnych dziełach scenicznych uwydatniony także w sferze muzycznej, co dokonało się poprzez wykorzystanie nawiązań do tradycji polskich tańców narodowych czy dzięki wprowadzeniu cytatów bądź stylizacji polskich.

Wątki polskie występują w kilkunastu dziełach operetkowych, których czas powstania obejmuje półwiecze, od Der Bettelstudent Carla Millöckera (I882) po Die schöne Carlotti (I943) autorstwa Willy'ego Czernika. W tym bogatym repertuarze zaznacza się przede wszystkim tendencja do traktowania elementów polskich jako nośników egzotyki, a odmienna kultura Polaków wprowadza atrakcyjny koloryt i klimat w tok zdarzeń scenicznych. Wypada tu jednak wyróżnić kilka operetek, w których problematyce kwestie społeczne i kulturowe związane z polskim środowiskiem dochodzą w sposób szczególny do głosu. Ich twórcy nie ograniczyli się przy tym do potraktowania Polaków jako egzotycznej grupy narodowościowej, wnoszącej atrakcyjny element kontrastu do zasadniczej fabuły utworów, lecz spróbowali w pogłębiony sposób zaprezentować związane z tym środowiskiem narodowym istotne kwestie polityczne i kulturowe. Nie do pominięcia jest kontekst historyczny, czyli okoliczności i czasy, w jakich powstawały te utwory. Oczywistym punktem zwrotnym w sposobie potraktowania Polaków wydaje się rok I9I8, moment odzyskania przez Polskę niepodległości po okresie ponad stu lat zaborów i nieobecności kraju na mapie Europy. Problemem badawczym, który stanowi zasadniczy zakres niniejszych badań, stało się ustalenie, czy i w jakim zakresie zmiana politycznej sytuacji narodu polskiego w I9I8 r. wpłynęła na sposób przedstawiania problematyki polskiej w operetkach niemieckich. W celu prześledzenia tej kwestii podjąłem badania dotyczące

3 Zagadnienie obecności tematyki polskiej w operetce zostało poruszone przez Oswalda Panagla, który w niewielkim artykule omawia problematykę czterech operetek: Der Bettelstudent (I882) Carla Millöckera, Polenblut (1913) Oskara Nedbala, Der letzte Walzer (1920) Oscara Strausa oraz Die blaue Mazur (1920) Franza Lehára, zob.: Oswald Panagl, „Solang 's noch solche Frauen gibt, ist Polen nicht verloren». Identitätskrisen und Solidaritätsstiftung auf der Operettenbühne”, w: Politische Mythen und nationale Identitäten im (Musik-) Theater: Vorträge und Gespräche des Salzburger Symposions 20oI, red. Peter Csobádi i in., Anif-Salzburg 2003, t. 2, s. 829-842. Jak się wydaje, jest to jedyne dotychczasowe opracowanie poświęcone problematyce polskiej w niemieckich operetkach. 
pięciu operetek, które powstały w XX w., w okresie do wybuchu II wojny światowej. Uwzględnienie zarówno utworów mających swe premiery przed 1918 r., jak i dzieł stworzonych już w latach dwudziestych i trzydziestych XX w., umożliwia wyraziste przeanalizowanie badanego problemu.

Repertuar wybranych pięciu dzieł operetkowych wygląda następująco:

Tab. I. Operetki niemieckojęzyczne o tematyce polskiej.

\begin{tabular}{|c|c|c|c|c|}
\hline & Autorzy tekstu & Kompozytor & Tytuł & Miejsce i data premiery \\
\hline I. & $\begin{array}{l}\text { Curt Kraatz, Georg } \\
\text { Okonkowski, Alfred } \\
\text { Schönfeld }\end{array}$ & $\begin{array}{l}\text { Jean Gilbert (Max } \\
\text { Winterfeld) }\end{array}$ & $\begin{array}{l}\text { Polnische } \\
\text { Wirtschaft }\end{array}$ & $\begin{array}{l}\text { Cottbus, Stadt-Theater, } \\
26 \text { XII I909 r. } \\
\text { (2. wersja Berlin, Thalia- } \\
\text {-Theater, 6 VIII I9Io r.) }\end{array}$ \\
\hline 2. & $\begin{array}{l}\text { Leo Stein, Evgenya } \\
\text { Spero }\end{array}$ & Oskar Nedbal & Polenblut & $\begin{array}{l}\text { Wiedeń, Carl-Theater, } \\
25 \text { X I9I3 r.; premiera } \\
\text { polska: Warszawa, Teatr } \\
\text { Nowości, I4 IX I9I5 r. }\end{array}$ \\
\hline 3. & $\begin{array}{l}\text { Julius Brammer, } \\
\text { Alfred Grünwald }\end{array}$ & Oscar Straus & Der letzte Walzer & $\begin{array}{l}\text { Berlin, Berliner Theater, } \\
\text { I2 II I920 r.; premiera } \\
\text { polska: Lwów, Teatr Miejski, } \\
28 \text { XI I921 }{ }^{6}\end{array}$ \\
\hline 4. & $\begin{array}{l}\text { Leo Stein, Béla } \\
\text { Jenbach }\end{array}$ & Franz Lehár & Die blaue Mazur & $\begin{array}{l}\text { Wiedeń, Theater an } \\
\text { der Wien, } 28 \text { V I920 r.; } \\
\text { premiera polska: Lwów, } \\
\text { Teatr Miejski, 29 IV } \text { 192I }^{7}\end{array}$ \\
\hline 5. & $\begin{array}{l}\text { Alfred Grünwald, } \\
\text { Fritz Löhner-Beda }\end{array}$ & Joseph Beer & Polnische Hochzeit & $\begin{array}{l}\text { Zurych, Stadttheater, } \\
3 \text { IV } 1937^{8}\end{array}$ \\
\hline
\end{tabular}

Dwa pierwsze spomiędzy wymienionych dzieł miały premiery jeszcze przed wybuchem I wojny światowej, trzy kolejne - w okresie międzywojennym. We wszystkich tych operetkach problematyka polska przenika do zasadniczych wątków akcji, ale tylko trzy dzieła mają tytuły wskazujące bezpośrednio na Polskę: Polnische Wirtschaft, Polenblut oraz Polnische Hochzeit. Te tytuły odsyłają od razu do stereotypowych wyobrażeń na temat Polski i Polaków, podzielanych przez społeczność niemiecką: brak

4 Ta operetka prawdopodobnie nigdy nie była wykonywana w Polsce, na co miał wpływ niepochlebny sposób przedstawienia polskiego środowiska: „Z głośniejszych jego [Jeana Gilberta - R.D.G.] utworów niewystawianych w Polsce trzeba wspomnieć nieprzyjazne dla nas, hakatystyczne, zapomniane już zresztą Polnische Wirtschaft (1910) i Das Puppchen (1912)", Lucjan Kydryński, Przewodnik operetkowy: wodewil, operetka, musical, Kraków 1977, s. I88.

5 Ibid., s. 463. Ta operetka doczekała się szeregu realizacji w Polsce także po II wojnie światowej, zob. np. strona http://encyklopediateatru.pl/sztuki/2I8I/polska-krew, dostęp II III 2019.

6 Małgorzata Komorowska, Teatry muzyczne drugiej Rzeczypospolitej, Warszawa 1997, s. 79.

7 Ibid., s. 79.

8 Wydaje się, że także ta operetka dotychczas nie była wystawiana w Polsce. 
gospodarności i bałagan (Polnische Wirtschaft), krewki i gwałtowny temperament (Polenblut) oraz skłonność do wystawnego świętowania (Polnische Hochzeit). Trzeba jednak zauważyć, że każdy tego typu negatywny wizerunek uzyskuje w toku fabuły poszczególnych operetek swoiste przewartościowanie, prowadzące do pozytywnej ewaluacji polskości. Z kolei tytuł Die blaue Mazur odnosi się do polskiej tradycji, w której do ostatniego tańca balu - mazura - mężczyzna zapraszał wybrankę swego serca, co interpretowano poniekąd jako deklarację matrymonialną. Przywołanie tego zwyczaju w tytule operetki miało jednak charakter pewnej pomyłki, bowiem w Polsce ten szczególny taniec zwany jest nie błękitnym, lecz białym mazurem9. Jedynie tytuł operetki Oscara Strausa Der letzte Walzer nie wskazuje w żadnym stopniu na problematykę polską, podkreślając w zamian wszechobecny w repertuarze operetkowym żywioł walca.

Akcja Polnische Wirtschaft rozgrywa się w Berlinie i w podupadłym wielkopolskim majątku Groß-Karschau, którego właścicielem jest Willy Hegewaldt, żyjący w separacji ze swoją polską żoną Margą. Willy ma ochotę na nowy związek małżeński z Eriką, córką berlińskiego radcy Mangelsdorfa, ale na przeszkodzie temu stają kwestie majątkowe. Otóż Marga odziedziczyła Groß-Karschau po ciotce, dziwaczne wymogi testamentu sprawiają jednak, że ona wraz z mężem muszą udawać szczęśliwe małżeństwo, by uniknąć przepadku posiadłości na rzecz innych członków rodziny. Corocznie, w dniu 30 sierpnia wszyscy krewni przybywają do Groß-Karschau, by skontrolować, czy małżonkowie nadal żyją w zgodnym stadle. Podczas takiego zjazdu rodzinnego Willy i Marga prezentują się jako przykładne małżeństwo, bowiem po szeregu perypetii Willy zdołał jednak zdecydować się na powrót do Margi. Osamotniona Erika łączy się zaś z poetą Hansem Fiedlerem, którego wcześniej Marga wysłała do Berlina w celu nakłonienia męża do powrotu do domu ${ }^{\mathrm{IO}}$.

Główny bohater operetki Polenblut, Hrabia Bolesław (Bolo) Barański bawi się w Warszawie podczas karnawału, zaniedbując swój podupadły majątek w Krasnowoli. Ma poznać Helenę, osobę zaradną i przedsiębiorczą, córkę przyjaciela rodziny, Jana Zaremby, ale znacznie bardziej ceni sobie rozrywkowy tryb życia i towarzystwo tancerki Wandy ze stołecznej opery. Rozczarowana tym Helena postanawia uciec się do podstępu: za jakiś czas przybywa wraz z przyjacielem Bola, Broniem Popielem, do Krasnowoli, gdzie Bronio przedstawia ją jako Marynię, energiczną gospodynię szukającą pracy. Bolo przyjmuje Marynię, której bardzo szybko udaje się doprowadzić do wyraźnej poprawy kondycji dworu. Zadowolony i coraz bardziej nią zafascynowany Barański zamierza nawet - nie zważając na różnicę stanów - wziąć ją za żonę. Wtedy przyjeżdża z Warszawy tancerka Wanda, która wyjawia prawdę: cudowną gospodynią

9 Lucjan Kydryński, Usta milczq dusza śpiewa. Opowieść o życiu i twórczości Franciszka Lehára, Warszawa I992, s. I32.

IO Jean Gilbert, Polnische Wirtschaft. Posse in drei Akten, Berlin 1929 Alrobi Musikverlag. 
jest Helena, podstępem usiłująca zdobyć serce Barańskiego. Dumna Helena zamierza zrezygnować z małżeństwa, jednak Bolo nie pozwala jej odejść i prosi o jej rękę. Zawiedzionej Wandzie pozostaje tylko związek z Broniem ${ }^{\text {II }}$.

Zasadniczy wątek problemowy operetki Der letzte Walzer tworzą losy warszawskiego romansu Wiery Lizawiety Opalińskiej i hrabiego Dymitra Sarrasowa. Ich znajomość zostaje zawarta w nietypowych okolicznościach: Dymitr obronił ją przed natrętnymi zalotami księcia Pawła, który z zemsty oskarżył hrabiego i uwięził go w swoim zamku. By upokorzyć Wierę, książę Paweł zmusza ją do małżeństwa ze starym generałem Miecu (Mieciu?) Krasińskim. Podczas wieczoru poprzedzającego zaślubiny organizowany jest bal, na który zezwolono przybyć także Dymitrowi pod przysięgą, że wróci do celi. Wiera tańczy z Dymitrem tytułowego ostatniego walca, organizując ucieczkę ukochanego, na którą ten jednak nie decyduje się, nie chcąc łamać danego słowa honoru. Szukając sposobu na przełamanie impasu, Wiera decyduje się kolejnego ranka na podstęp: zgadza się przybyć do zamku księcia Pawła. Stosując różne uwodzicielskie triki, w ramach rzekomego eksperymentu miłosnego zyskuje na jeden dzień władzę nad zamkiem księcia. Jej pierwszą decyzją staje się uwolnienie Dymitra i organizacja błyskawicznego z nim ślubu ${ }^{\mathrm{I2}}$.

Tytułowy mazur w Die blaue Mazur odgrywa szczególną rolę w finale operetki, będąc przypieczętowaniem szczęśliwego zakończenia losów głównych bohaterów: hrabiego Juliana Olińskiego i jego młodej żony Blanki von Lossin. Choć akcja operetki rozpoczyna się weselem tych dwojga, to szybko okazuje się, że Julian tęskni do wesołego stylu życia i licznych kobiet, z którymi musi się rozstać. Blanka przypadkowo dowiaduje się o tym i - zrozpaczona - zgłasza się po pomoc do barona von Reiger, dawnego przyjaciela jej matki. Szlachcic przyjmuje ją do swego domu, w którym mieszka wraz z prowadzącym podwójne życie siostrzeńcem: rzekomo porządnym i pracowitym Engelbertem, który w nocy przemienia się w rozpustnika Adolara. Po pewnym czasie Julian odnajduje Blankę i usiłuje ją odzyskać, uciekając się do podstę$\mathrm{pu}$ - proponuje anulować ich małżeństwo i darować wolność Blance, którą w międzyczasie zafascynował Engelbert. Gdy jednak okazuje się, że Engelbert i Adolar to ta sama osoba, Blanka porzuca go. Engelbert musi zadowolić się związkiem z tancerką Gretl. Blanka uświadamia sobie, że kocha męża i postanawia mu przebaczyć. Dzieje się to podczas balu - w trakcie mazura Julian odzyskuje żonę ${ }^{13}$.

II Volker Klotz, „Nedbal: Polenblut”, w: Pipers Enzyklopädie des Musiktheaters, t. 4, red. Carl Dahlhaus, München-Zürich I99I, s. 396-399. Temat, choć prezentuje polskie środowisko, został zaczerpnięty z jednego z opowiadań Aleksandra Puszkina Barysznia-kriestjanka, zawartego w tomie opowiadań Powiesti pokojnogo Iwana Pietrowicza Betkina (1830).

I2 Der letzte Walzer. Operette in drei Akte von Julius Brammer und Alfred Grünwald, Musik von Oscar Straus, Textbuch der Gesänge, Berlin-München I92I Der Masken-Verlag; zob. też http://www.operetten-lexikon. info/?menu=237\&lang=I, dostęp 2 I 2019 .

I3 Leo Stein, Béla Jenbach, Franz Lehár, Die blaue Mazur. Operette in zwei Akten, drei Bildern, Wien I920/1948 Glockenverlag. 
W prologu Polnische Hochzeit młody hrabia Bolesław Zagórski w przebraniu i z fałszywym paszportem przekracza granicę pomiędzy zaborem austriackim a rosyjskim, postanawiając wrócić do ojczystego majątku. Kilka lat wcześniej musiał opuścić ojczyznę, kiedy jego ojciec, polski patriota, został wypędzony przez Rosjan za propolską działalność patriotyczną. Tęskniąc za ukochaną Jadzią, córką zubożałego barona Mietka Ogińskiego, Bolesław wraca w przebraniu służącego do rodzinnego majątku, którym zarządza teraz jego stryj Staszek Zagórski. Bogaty stryj słynie z licznych małżeństw, rozwiódł się właśnie z piątą żoną i postanawia ożenić się z Jadzią. Dowiadując się o tym, Bolesław wyjawia swą prawdziwą tożsamość, domagając się zwrotu majątku i objawiając chęć poślubienia Jadzi. Reakcją stryja staje się wezwanie ochrany i szantaż Jadzi: albo wyjdzie ona za mąż za Staszka, albo ten zdradzi Rosjanom prawdziwą tożsamość Bolesława. Zrozpaczona Jadzia zgadza się na ślub, chcąc uratować ukochanego. Jej przedsiębiorcza przyjaciółka Suza organizuje ucieczkę Bolesława i Jadzi, jednak Staszek już wcześniej przygotował pościg i uciekinierzy zostają przyprowadzeni do pałacu. Odbywa się ceremonia weselna, po której okazuje się, że Staszek poślubił nie Jadzię, lecz skrytą pod welonem panny młodej Suzę. Jako żona, Suza natychmiast staje się despotyczna i władcza, co powoduje szybką chęć unieważnienia ślubu przez Staszka. Musi on jednak zaakceptować warunki Suzy: zwrot majątku Bolesławowi, jego ślub z Jadzią oraz zgodzić się na związek Suzy z jej ukochanym Kazimierzem ${ }^{\mathrm{I}}$.

Czas akcji we wszystkich pięciu operetkach wydaje się zaskakująco ujednolicony, gdyż zdarzenia rozgrywają się na początku drugiej dekady XX wieku. Dla dwóch operetek przedwojennych oznaczało to usytuowanie akcji w czasach, w których następowały ich premiery. Z kolei w przypadku Der letzte Walzer, mającego premierę w 1920 r., akcja została przeniesiona do roku I9IO, czyli do rzeczywistości przedstawionej w Polnische Wirtschaft i Polenblut. Podobne ramy czasowe zdaje się mieć fabuła stworzonej w 1937 r. operetki Polnische Hochzeit - w libretcie pojawia się informacja o usytuowaniu akcji przed I wojną światową. Ale i lapidarna uwaga o „czasach współczesnych", w jakich rozgrywa się akcja Die blaue Mazur, też wskazuje na rzeczywistość sprzed I wojny, gdyż w przedstawionych w fabule realiach istnieją granice zaborów: rosyjskiego i austriackiego sprzed 1918 roku. W żadnym z librett nie ma zresztą mowy ani o wojnie, ani o kwestii niepodległości Polski. Wobec takiej niespodziewanej zgodności czasu przedstawionego w fabułach wszystkich omawianych operetek uzasadniona staje się analiza zjawisk społecznych, uwarunkowań politycznych i odniesień do polskiej problematyki.

Miejsce akcji również wydaje się podobne. W Polnische Wirtschaft zdarzenia rozgrywają się Niemczech i w zaborze pruskim: w Berlinie i podupadtym wielkopolskim majątku Groß-Karschau; w Die blaue Mazur akcja toczy się w okolicach Wiednia.

I4 Polnische Hochzeit, Operette in drei Akten (mit einem Vorspiel) von Alfred Grünwald und Dr. Fritz Löhner, Musik von Joseph Beer [libretto], Wien I936 Wiener Operettenverlag. 
Pozostałe trzy operetki przedstawiają rzeczywistość polską widzianą z perspektywy zaboru rosyjskiego: Warszawy (Polenblut, Der letzte Walzer) lub prowincjonalnych majątków ziemskich (Polenblut, Polnische Hochzeit). Usytuowanie akcji pomiędzy miastami stołecznymi (Warszawa, Berlin, Wiedeń) a prowincją (wiejskie majątki ziemskie należące do bohaterów) determinuje przebieg fabuły każdego z tych utworów.

Tab. 2. Miejsce akcji omawianych operetek.

\begin{tabular}{|l|l|}
\hline \multicolumn{1}{|c|}{ Tytuł } & \multicolumn{1}{c|}{ Miejsca akcji } \\
\hline Polnische Wirtschaft & Berlin, majątek Groß-Karschau (zabór pruski) \\
\hline Polenblut & Warszawa, majątek Krasnowola (zabór rosyjski) \\
\hline Der letzte Walzer & Warszawa, posiadłość ziemska w okolicy Warszawy \\
\hline Die blaue Mazur & Wiedeń, posiadłość w okolicach Wiednia \\
\hline Polnische Hochzeit & granica austriacko-rosyjska, majątek ziemski Starosław w zaborze rosyjskim \\
\hline
\end{tabular}

Galeria bohaterów także okazuje się zaskakująco jednorodna, co świadczy o stereotypowym podejściu do konstrukcji postaci. Liczne podobieństwa w tym zakresie, które umożliwiają zarazem dokonywanie porównań, są spowodowane czarno-białym systemem wartości, typowym dla sztuki przeznaczonej dla środowiska mieszczańskiego. Główny bohater to mężczyzna życiowo zagubiony, będący przedstawicielem klasy właścicieli ziemskich: albo typ utracjusza i hulaki, który przedkłada rozrywki wielkiego świata nad codzienne obowiązki, albo niezaradny, niekiedy nieodpowiedzialny romantyk, niepotrafiący radzić sobie w rzeczywistości społecznej. Noszą oni na ogół tradycyjne polskie imiona oraz stereotypowe polskie nazwiska zakończone na -ski, takie jak Julian Oliński (Die blaue Mazur), Bolesław Barański (Polenblut) czy Bolesław Zagórski (Polnische Hochzeit). W pozostałych dwóch operetkach mężczyzna będący głównym bohaterem wywodzi się ze środowiska zaborców - jest albo Niemcem (Willy Hegewaldt w Polnische Wirtschaft), albo Rosjaninem (Dymitr Sarrasow w Der letzte Walzer), ale jego charakterystyka psychologiczno-emocjonalna okazuje się tożsama z profilami osobowości pierwszoplanowych postaci Polaków z pozostałych operetek. Można stwierdzić, że istotą dramaturgii omawianych utworów stała się konieczność aktywnego działania kobiet, które czuwają nad tym, by męski protagonista nie poniósł klęski i osiagnął status pozytywnego bohatera odpowiadający wyobrażeniom mieszczańskiej publiczności.

Tab. 3. Główni bohaterowie operetek.

\begin{tabular}{|l|l|l|}
\hline \multicolumn{1}{|c|}{ Operetka } & \multicolumn{1}{c|}{ Główny bohater } & \multicolumn{1}{c|}{ Główna bohaterka } \\
\hline Polnische Wirtschaft & Willy Hegewaldt & Marga \\
\hline Polenblut & Bolesław Barański & Helena (Marynia) \\
\hline Der letzte Walzer & Dymitr Sarrasow & Wiera Lizawieta \\
\hline Die blaue Mazur & Julian Oliński & Blanka \\
\hline Polnische Hochzeit & Bolesław Zagórski & Jadzia \\
\hline
\end{tabular}


Również główne bohaterki tworzą szereg postaci o bardzo podobnych rysach charakteru. Za każdym razem jest to rozsądna, świadoma kobieta, która zdecydowanie odpowiada stereotypowym wyobrażeniom żony: kochająca, odpowiedzialna, gospodarna, skłonna do poświęceń. Marga, Helena, Wiera Lizawieta, Blanka i Jadzia wszystkie te pierwszoplanowe postaci kobiece wykazują się aktywnością i dbałością o trwałość związku ze swym niekiedy nieodpowiedzialnym lub niesamodzielnym partnerem, a w razie kłopotów sięgają po podstęp i intrygę, sprytnie zapobiegając zbliżającej się katastrofie grożącej ukochanemu mężczyźnie. Marga, bohaterka Polnische Wirtschaft, wyraża nawet swoiste przekonanie o sile osobowości polskich kobiet, charakteryzując cechy Polek w swojej wypowiedzi wokalnej:

Tanzt die Polin, Pulse fliegen,

Männer alle wir besiegen,

Temp'rament ist kolossal,

Liebesqual gleich überall!

Polin hat von allen Reizen,

Andre damit einzeln geizen,

Exquisitesten voran,

Sagt doch jeder Mann.

\author{
Tańczy Polka, puls tętni. \\ Zdobywamy wszystkich mężczyzn. \\ Temperament mamy olbrzymi, \\ W ślad za nim idzie pragnienie miłości. \\ Polka ma mnóstwo uroku, \\ Czego pozbawione są inne kobiety. \\ Wydaje się najwspanialsza, \\ Co potwierdza każdy mężczyzna.
}

Przykł. I. Polnische Wirtschaft, finał I aktu, nr 3, partia Margi.

Te powtarzalne charaktery pary głównych bohaterów okazują się podczas dokładniejszej analizy znacznie bardziej zróżnicowane. W trzech operetkach: Polnische Wirtschaft, Polenblut oraz Die blaue Mazur bohaterowi grozi upadek moralny, będący konsekwencją jego hulaszczego trybu życia. Uleganie skłonnościom do stołecznych rozrywek i uciech oraz zaniedbywanie obowiązków zarządcy majątku zagraża jego społecznej pozycji, jednak za sprawą pozytywnej partnerki następuje zmiana osobowości i powrót protagonisty na drogę akceptowanych zachowań i ideałów mieszczańskich. Najsilniejszą dominantę stanowi za każdym razem pragnienie stworzenia szczęśliwego związku małżeńskiego opartego na prawdziwej miłości, co w oczywisty sposób koresponduje z oczekiwaniami głównych bohaterek.

Jednak fabuła dwóch późniejszych dzieł - Der letzte Walzer i Polnische Hochzeitzawiera nieco odmienne treści, które można traktować jako pogłębienie problematyki związane z wprowadzeniem elementu politycznego. W obu tych utworach główny bohater znajduje się w sytuacji zagrożenia wynikającego z jego działalności społecznej lub politycznej - Dymitr Sarrasow szlachetnie broni dwie damy przed gwałtownością rozpustnika, księcia Pawła, natomiast Bolesław Zagórski jest synem polskiego patrioty walczącego z rosyjskim zaborcą. W tym kontekście aktywne działanie kobiet chroniących swych ukochanych mężczyzn przyjmuje inny charakter: organizują one ucieczkę bohaterów w bezpieczne miejsce, zapobiegają ich uwięzieniu lub śmierci. 
Trzeba dla porządku dodać, że w Polnische Hochzeit rolę osoby chroniącej głównego bohatera przejmuje inna kobieta - Suza, będąca znacznie bardziej energiczną i zdecydowaną postacią niż Jadzia, ukochana protagonisty. Poważniejsze rysy osobowości tych kobiet - Jadzi, Suzy i Wiery - decydują o innym typie dramaturgii operetki, co zdaje się łączyć je z niemiecką tradycją operową, wyznaczoną chociażby wizerunkiem Leonory z Beethovenowskiego Fidelia.

Takie polityczne wątki wydają się zdecydowanie nietypowe dla gatunku operetki, która miała przecież głównie dostarczać przyjemnej rozrywki. Nie sposób sobie wyobrazić, by te treści mogły być prezentowane w Polsce w czasach zaborów, mogłyby bowiem sprawiać wrażenie przemycania treści rewolucyjnych lub antypaństwowych. Jest to, jak się wydaje, najpoważniejsza zmiana problematyki operetek o tematyce polskiej i cecha charakteryzująca dzieła prezentowane już po I9I8 roku. Pochodząca z tego samego czasu co Der letzte Walzer operetka Die blaue Mazur wydaje się więc pod względem problematyki mniej aktualna niż dwa wspomniane dzieła prezentujące głębsze treści - Der letzte Walzer i Polnische Hochzeit.

Sentymentalny rys akcji, niezbędny w utworze będącym mieszczańską rozrywką o rysach moralizatorskich, wypada też skonfrontować z wyobrażeniami odnoszącymi się do narodowości, gdyż w dramaturgii wszystkich pięciu dzieł pojawiają się tak Polacy, jak i obywatele państw zaborczych - Niemcy, Austriacy i Rosjanie. Mimo faktu, że fabułę tych utworów wyznacza rzeczywistość rozbiorowa, jedynie w akcji Polnische Hochzeit można zauważyć wyraźne odniesienia do kwestii politycznych. Zasadniczy konflikt kreujący dramaturgię tej operetki - rywalizacja stryja i bratanka w staraniach o zdobycie ręki Jadzi - nakłada się na głębsze kwestie natury politycznej i moralnej. Otóż stryj, Staszek Zagórski, który jest mocno związany z rosyjskim zaborcą, wzywa na pomoc carską ochranę i nie waha się użyć swych układów politycznych dla realizacji cynicznych planów osobistych. Jego opozycjonista, bratanek Bolesław Zagórski, ujawnia rysy patrioty i bohatera, ryzykując życiem, przedostaje się bowiem pod fałszywym nazwiskiem z zaboru austriackiego na ziemie polskie (do zaboru rosyjskiego). Ten powrót, motywowany tęsknotą za ojczyzną, jest ryzykowny głównie z uwagi na dawniejszą patriotyczną i narodową działalność jego ojca, za którą został zmuszony do emigracji. Jako że problematyka ta zostaje wyeksponowana już na samym początku operetki, w prologu (Vorspiel), wyznacza ona główną oś fabuły i wydaje się niebanalnym pomysłem budowania dramaturgii całego dzieła. Patriotyzm Bolesława zostaje podkreślony również w dalszym toku Polnische Hochzeit, gdy po powrocie do rodzinnego majątku ulega on wzruszeniu, śpiewając w rytmie mazurka o ukochanej ojczyźnie, do której zwraca się zresztą w ojczystym, polskim języku: 
Polska! Polska!

Alles, was wir lieben, liegt in diesem Wort!

Polska! Polska!

Laßt die alten Lieder klingen!

Polenland, mein Heimatland!

Jetzt bin ich wieder dein!

Was auch immer sei,

Einmal wirst du frei!

Polenland, mein Heimatland!

Jetzt bin ich wieder dein!

Herrlich ist's, daheim zu sein!

Wo solche Blumen blüh'n,

die schönsten Frau'n,

Wohin die Augen seh'n

Flammenheiße Blicke glüh'n;

Die Polin ist so schön!

Polenland, mein Heimatland!

Jetzt bin ich wieder dein!

Herrlich ist's, daheim zu sein!

Halka! Talka!

Kommt, ihr drallen Mädel,

alle kommt zu mir!

Kasja, Stasja,

Laßt uns sie Mazurka tanzen.

Manja, Stanja,

heute sind wir lustig, heute tanzen wir!

Karja, Marja!

Kommt, wir woll'n Mazurka tanzen.
Polska! Polska!

Wszystko, co kochamy, znajduje się w tym słowie!

Polska! Polska!

Niech rozbrzmiewają stare pieśni!

Kraju Polaków, mój kraju ojczysty!

Teraz jestem znów twój!

Jak zawsze było,

Tak i teraz staniesz się wolny!

Kraju Polaków, mój kraju ojczysty!

Teraz jestem znów twój!

Cudownie być znowu w domu!

Gdzie kwitną takie kwiaty,

Najpiękniejsze kobiety,

Gdzie tylko rzucisz okiem,

Płoną ogniste spojrzenia.

Polka jest tak piękna!

Kraju Polaków, mój kraju ojczysty!

Teraz jestem znów twój!

Cudownie być znowu w domu!

Halka! Talka!

Chodźcie, hoże dziewczęta

Chodźcie do mnie wszystkie!

Kasia, Stasia

Zatańczmy mazurka.

Mania, Stania

Dziś jesteśmy weseli, dziś tańczymy!

Karia, Maria!

Chodźcie, zatańczmy mazurka.

Przykł. 2. Joseph Beer, Polnische Hochzeit, akt I, nr 4, scena przybycia Bolesława.

Poważniejszy wątek patriotyczno-narodowy znacząco odróżnia dramaturgię Polnische Hochzeit od pozostałych operetek, których fabułę budują głównie stosunki miłosne i towarzyskie. Można nawet stwierdzić, że w prezentowanych utworach relacje Polaków z przedstawicielami społeczności zaborczych - Niemcami, Austriakami i Rosjanami - układają się bezproblemowo i harmonijnie, jako że nie powstają żadne konflikty ani konfrontacje narodowe, a przedstawiciele wszystkich nacji zdają się mieć analogiczne prawa i możliwości. Nieco odmiennie prezentuje się jedynie Der letzte Walzer: mimo umiejscowienia akcji tego dzieła w Warszawie i wprowadzenia na scenę polskich bohaterów, główne wątki dotyczą losów Rosjan: Wiery Lizawiety i Dymitra Sarrasowa. W toku tego dzieła pojawia się zresztą więcej nawiązań i stylizacji rosyjskich niż polskich, łącznie z wprowadzeniem brzmienia bałałajek jako 
charakterystycznej cechy muzyki narodowej. Można to interpretować jako przejaw swoistego cliché charakteryzującego zachodnie spojrzenie na kulturę Słowian, które cechuje się analogicznym postrzeganiem Polaków i Rosjan, łączonych nie tylko ze względu na pokrewieństwo językowe, ale i na pewne wspólne elementy kultury i temperamentu' ${ }^{15}$.

W dramaturgii Polenblut wątki narodowe wydają się bardziej wyrafinowane, gdyż skoro wszyscy bohaterowie są tu Polakami, nie ma żadnych szans na przedstawienie jakichkolwiek konfliktów narodowych. Jednak bliższa analiza prowadzi do interesujących wniosków dotyczących sytuacji społeczno-politycznej narodu polskiego. Protagonista, utracjusz Bolesław Barański, krąży pomiędzy Krasnowolą, swoim podupadającym majątkiem ziemskim, a stołeczną Warszawą - warto zauważyć, że oba te miejsca znajdują się w zaborze rosyjskim. Zasadniczą intrygę Polenblut wyznacza działalność głównej bohaterki, Heleny, która w przebraniu zarządczyni znacząco wpływa na poprawienie się sytuacji ekonomicznej dworu Barańskiego. I choć w libretcie tej operetki nie figuruje wprost sugestia, że Helena wywodzi się z zaboru austriackiego, to przesadne wyposażenie tej postaci w jednoznacznie pozytywne cechy charakteru, stereotypowo utożsamiane z cnotami kultury niemieckiej bądź austriackiej, komunikowało z pewnością ówczesnej publiczności jej związki ze środowiskiem spoza kręgu oddziaływania mentalności rosyjskiej ${ }^{16}$. Sugestię, że Helena przybyła z Galicji, zdaje się wyraziście podkreślać strona muzyczna tej operetki, w której istotną rolę odgrywa krakowiak, polski taniec narodowy o nazwie wskazującej na stolicę Galicji. Taką interpretację potwierdza również szata graficzna wyciągu fortepianowego Polenblut - winieta pierwodruku ukazuje bohaterów w stroju krakowskim ${ }^{17}$.

Sposób kreacji charakterów polskich postaci, a także odwzorowanie lokalnych zwyczajów i tradycji decydują o uwiarygodnieniu zdarzeń przedstawionych w fabułach operetek. Dożynki, biały (błękitny) mazur, witanie nowożeńców chlebem i solą, uroczystości rodzinne, bogate ceremonie weselne - wszystkie tego typu sytuacje mają niekiedy charakter cokolwiek egzotyczny dla niemieckiego czy austriackiego odbiorcy, ale wprowadzają lokalny, polski koloryt. Na końcu pierwszego aktu Die blaue Mazur protagonista Julian śpiewa tęskną dumkę (Polenlied) o ukochanej kobiecie,

I5 Zainteresowania tematyką związaną z losami i zwyczajami przedstawicieli różnych narodów wydają się w dziełach operetkowych tworzonych w pierwszych dekadach XX w. bardzo typowe i często spotykane. Derek B. Scott określa niemiecką operetkę tego czasu mianem "gatunku kosmopolitycznego” (a cosmopolitan genre), zwracając uwagę tak na rozmaite typy zainteresowań i tematyki, na przepływ stylistyk operetki, jak i na związek twórców gatunku ze środowiskiem żydowskiej diaspory, co umożliwiło światową dystrybucję tego repertuaru, zob.: Derek B. Scott, „Early twentieth-century operetta from German stage: A cosmopolitan genre”, The Musical Quarterly 99 (2016) nr 2, s. 254-279.

I6 W klasycznej pracy Richarda Traubnera pojawia się wręcz uwaga o tym, że Polenblut była operetką nietypową pod względem tak politycznym, jak i muzycznym: „Politically and musically, Polenblut was an oddity. Its composer was of Czechoslovakian origins, yet the play took place in Russian-occupied Poland", R. Traubner, op. cit., s. 282.

I7 Oskar Nedbal, Polenblut [wyciąg fortepianowy], Wien I9I3 Ludwig Doblinger K.G. 
przy czym wykonuje ją w języku polskim, co trzeba uznać za przejaw dążenia do realizmu w zakresie prezentacji środowiska narodowego. Oprócz konsekwentnego wykorzystywania polskiego tekstu uwagę zwraca wyrafinowana stylizacja muzyczna, przywodząca na myśl kresowe śpiewy ukraińskie.



Przykł. 3. Franz Lehár, Die blaue Mazur, dumka Juliana (Polenlied) ${ }^{18}$.

Nie są to jedyne sposoby ewokowania stereotypów narodowych w omawianych operetkach. Tytułowe określenie Die blaue Mazur odnosi się do polskiego zwyczaju, występującego w kręgach szlacheckich, a zwłaszcza kojarzonego ze środowiskiem wojskowym (znana polska pieśń Ostatni mazur), odnosi się więc do pewnego polskie-

I8 L. Stein, B. Jenbach, F. Lehár, Die blaue Mazur, op. cit., s. 90. 
go kodu kulturowego, akceptowanego i propagowanego w wielonarodowej kulturze Monarchii Habsburgów ${ }^{19}$. Sytuacja odtańczenia owego mazura przez parę głównych bohaterów w zakończeniu operetki Lehára staje się sposobem rozwiązania konfliktu dramatycznego i podkreśleniem lokalnego, polskiego zwyczaju.

Wprowadzenie przymiotnika wskazującego na polską tematykę w tytułach trzech z pięciu omawianych utworów może być wyrazem ogólnej fascynacji tematyką polską, ale wyznacza też pewne wymiary stereotypowego postrzegania Polski i Polaków z perspektywy Niemiec czy Austrii. „Polnische Wirtschaft” to termin pejoratywny, którego znaczenie kształtowało się przez kilka stuleci. Szczegółowo problematyka związana z tym pojęciem została prześledzona przez Huberta Orłowskiego w pracy Polnische Wirtschaft: nowoczesny niemiecki dyskurs o Polsce ${ }^{20}$. Zakres tytułowego pojęcia kształtował się od XVIII w. i był łączony ze stereotypowym postrzeganiem cech polskiej mentalności, takich jak brak właściwego zarządzania, prywata, nieodpowiedzialność czy brak stałych zasad ekonomicznych. Pojęcie to funkcjonuje zresztą do dziś w dyskursie niemieckim (i nie tylko) na określenie typowego dla Polaków braku gospodarności, prowadzącego do degrengolady i upadku.

Określenie „Polenblut” w tytule operetki Nedbala, sugerujące specyfikę polskiego temperamentu i osobowości bohaterów, też budzi pewne wątpliwości interpretacyjne. Jakkolwiek można by się spodziewać, że tytuł wskazuje na Helenę, bohaterkę pełną energii i inicjatywy, to jednak dla publiczności austriackiej uosobieniem polskiego charakteru były inne postaci z tej operetki: niegospodarny właściciel ziemski Bolesław Barański, jego pasożytniczy przyjaciel Bronio i lubieżna tancerka Wanda, z którą Bolesław wdaje się w romans. Ale pierwszoplanowa rola Heleny zdaje się sugerować i inne odczytanie tytułu, który mógł się wiązać z lansowaniem nowego pojmowania polskości. Pozytywnie oceniana postać Heleny to przejaw swoistej „pracy u podstaw”, kreowania odmiennego wizerunku Polaków, ich edukowania i cywilizowania ${ }^{21}$.

I9 Podobną rolę pełni np. scena podania przez Arabellę szklanki wody Mandryce w zakończeniu opery Arabella Richarda Straussa. To symboliczne przypieczętowanie akceptacji kandydata na męża miało wnosić do dzieła (również wystawionego w Wiedniu) koloryt lokalny związany z narodowym kręgiem chorwackim, z którego wywodził się Mandryka. Analogicznie można potraktować wspomnianą już dumkę Juliana, w której zastosowany został tekst w języku polskim. Takie wtręty w językach ludów zamieszkujących Monarchię Austro-Węgier pojawiały się niejednokrotnie w operetkach wiedeńskich, by wspomnieć np. stylizację na język czeski w finale I aktu Zemsty nietoperza Johanna Straussa juniora. Odwołania do oryginalnych kontekstów kulturowych w dziełach operetkowych nie wykluczały jednak także adaptacji, transformacji i przystosowywania lokalnych typów zachowania do przyzwyczajeń konkretnego typu publiczności. Na ten temat por. D.B. Scott, op. cit., s. 26I-263.

20 Hubert Orłowski, Polnische Wirtschaft: nowoczesny niemiecki dyskurs o Polsce, przekł. Isabela Sellmer, Sven Sellmer, Olsztyn 1998. Praca ta stanowi doskonale udokumentowane źródłowo studium na temat kształtowania się wyobrażeń i stereotypów Polaków w oczach Niemców.

2I W jednej z wersji tekstu libretta operetki Polenblut w końcowej scenie Mirski, postać drugoplanowa, wygłasza uwagę: „Polenblut. Eine romantische Mischkulanz aus Adelsstolz und Bauernehre”, co sugeruje charakterystykę osobowości polskich bohaterów. Wydaje się jednak, że ta uwaga została dodana w późniejszych wersjach operetki. 
Tytułowe „polskie wesele” w operetce Polnische Hochzeit Josepha Beera sugeruje natomiast istnienie tradycji hucznego celebrowania zaślubin na ziemiach polskich. Według różnych świadectw zwyczaje wielodniowych zabaw i uczt weselnych były w Polsce od wieków przejawem stylu kultury szlacheckiej, której pozostałości, w nieco skromniejszej postaci, można obserwować i we współczesnych zachowaniach Polaków. Ale w kontekście fabuły operetki tytułowe określenie ma charakter dwuznaczny, wskazując również na intrygę, kiedy to podczas fałszywego ślubu Staszek Zagórski, negatywny bohater i zdrajca narodowy, łączy się nie z Jadzią, a z ucharakteryzowaną na nią jej przedsiębiorczą koleżanką, Polką Suzą. Upokorzenie Staszka przez Suzę - jędzę wymagającą absolutnego posłuchu - może być w tym kontekście interpretowane jako kara za kolaborację z Rosjanami, a tytułową polskość jego wesela wypada traktować jako wyraz stereotypowego przekonania o patriotyzmie Polaków i prymacie postaw narodowych nad sferą życia osobistego.

Jak zauważył Oswald Panagl, analizujący cztery operetki niemieckie o tematyce polskiej przedstawiane na scenach wiedeńskich (Der Bettelstudent, Polenblut, Der letzte Walzer oraz Die blaue Mazur), ten repertuar charakteryzuje się pewnymi elementami wspólnymi, możliwymi do zaobserwowania w tematyce i fabule. Są to, zdaniem autora: duma narodowa bohaterów, opór wobec obcego panowania, współdziałanie w momentach politycznego zagrożenia oraz szczęśliwe zakończenie (przynajmniej w sferze życia prywatnego bohaterów) ${ }^{22}$. Uwzględniając również dwie operetki, które nie były przedmiotem refleksji Panagla, można zgodzić się z jego uwagami i zaznaczyć, że element narodowej identyfikacji polskich bohaterów odgrywa bardzo istotną rolę w konstruowaniu dramaturgii wszystkich omawianych tu dzieł. Stwierdzić jednak wypada również, że kreacje osobowości bohaterów, tak mężczyzn, jak i kobiet, zostały ukształtowane w mało zindywidualizowany sposób, bez dążenia do pogłębienia indywidualnej charakterystyki. Dominują rozpowszechnione stereotypy, dotyczące żywego temperamentu i zdecydowania Polek oraz powszechnej skłonności Polaków do zabaw i rozrywek prowadzącej do zaniedbywania obowiązków.

Istotną rolę w kreowaniu jakości narodowych w strukturze omawianych dzieł operetkowych odgrywają kategorie muzyczne związane z charakterystyką polską. Dość typowe staje się wykorzystanie elementów muzyki narodowej, głównie tańców narodowych - mazura, krakowiaka i poloneza - dla charakterystyki boha-

22 „Im goldenen wie im silbernen Segment der österreichischen Operette lässt sich eine Nische ausmachen, die man als polnisches Genre bezeichnen könnte. Denn abseits aller zeitlichen und stilistischen Unterschiede und zusätzlich zum gemeinsamen Schauplatz gibt es einige durchgehende Merkmale: nationaler Stolz der Protagonisten, Widerstand gegen Fremdbestimmung, politischer Zusammenhalt in schwierigen Zeiten, schließlich - der Gattung gemäß - ein guter Ausgang, der zumeist privates Glück und öffentliche Wohlfahrt auf einen Nenner bringt", zob.: O. Panagl, op. cit., s. 839. 
terów polskich i związanych z nimi sytuacji scenicznych. Znaczenie mazura (czy mazurka) w kreowaniu aury polskości muzycznej wydaje się przy tym najbardziej uniwersalne - ten polski taniec narodowy został wykorzystany najobficiej w Die blaue Mazur, co w oczywisty sposób wynika z samej tematyki operetki. Jednak i w pozostałych dziełach mazurek okazuje się najbardziej oczywistym sposobem ewokowania polskości w muzyce. W rytmy krakowiaka obfituje głównie partytura Polenblut, natomiast taneczne stylizacje polonezowe - znacznie rzadsze - mają zastosowanie w zbiorowych scenach o charakterze uroczystości rodzinnych lub towarzyskich. W drugim akcie Polnische Hochzeit odświętny polonez śpiewany jest ze słowami „Noch ist Polen nicht verloren”, stanowiącymi niemieckie tłumaczenie początkowych słów Mazurka Dąbrowskiego. Ten tekst, przytoczony tu jednak bez kontekstu cytatu muzycznego, pełni funkcję przywołania polskiej tradycji, jednak charakter problematyki narodowej zostaje powiązany z aktualną sytuacją przedstawianą w operetce:

\footnotetext{
„Noch ist Polen nicht verloren!”

Heißt's im alten Heimatlied.

Noch ist Polen nicht verloren,

Wenn man solchem Glanz hier sieht.

's kommen Gäste, wohlgeboren,

Um zu seh'n die schöne Braut,

Die Graf Staschek sich erkoren.

Noch ist Polen nicht verloren.
}

\author{
„Jeszcze Polska nie zginęła!”, \\ Tak [to] brzmiało w starej pieśni narodowej. \\ Jeszcze Polska nie zginęła. \\ Kiedy widać tu taki przepych. \\ Przybywają szlachetnie urodzeni goście, \\ By zobaczyć piękną pannę młodą, \\ Którą wybrał dla siebie hrabia Staszek. \\ Jeszcze Polska nie zginęła.
}

Przykł. 4. Joseph Beer, Polnische Hochzeit, tekst poloneza z początku II aktu²3.

W dalszym przebiegu fabuły tej operetki następuje ceremonia weselna, w której ma miejsce scena taneczna, sprowokowana żądaniem Staszka, by zabrzmiał kujawiak, typowy dla polskich sytuacji tanecznych („Tanzt uns jetzt den Kujawiak, So tanzt man in Polen!”). Jednak faktycznie balet tańczy najpierw ognistego mazura (Polnischer Tanz. Mazur: Allegro con fuoco), a dopiero później następuje bardziej liryczny przebieg (Molto meno mosso, quasi andantino). W obu tych odcinkach zostały zacytowane rozpowszechnione melodie mazurkowe: Umart Maciek, umart oraz Jeszcze jeden mazur dzisiaj, które i współcześnie funkcjonują w polskiej popularnej kulturze muzycznej (przykł. 5). Niewątpliwie obecność tych idiomatycznie polskich cech muzycznych decydowała o atrakcyjności operetek i wprowadzeniu polskiego kolorytu, ale także - w pewnym stopniu - mogła powodować uwiarygodnienie przedstawianej problematyki narodowej.

Polnische Hochzeit, Operette in drei Akten [libretto], op. cit., s. 39. 


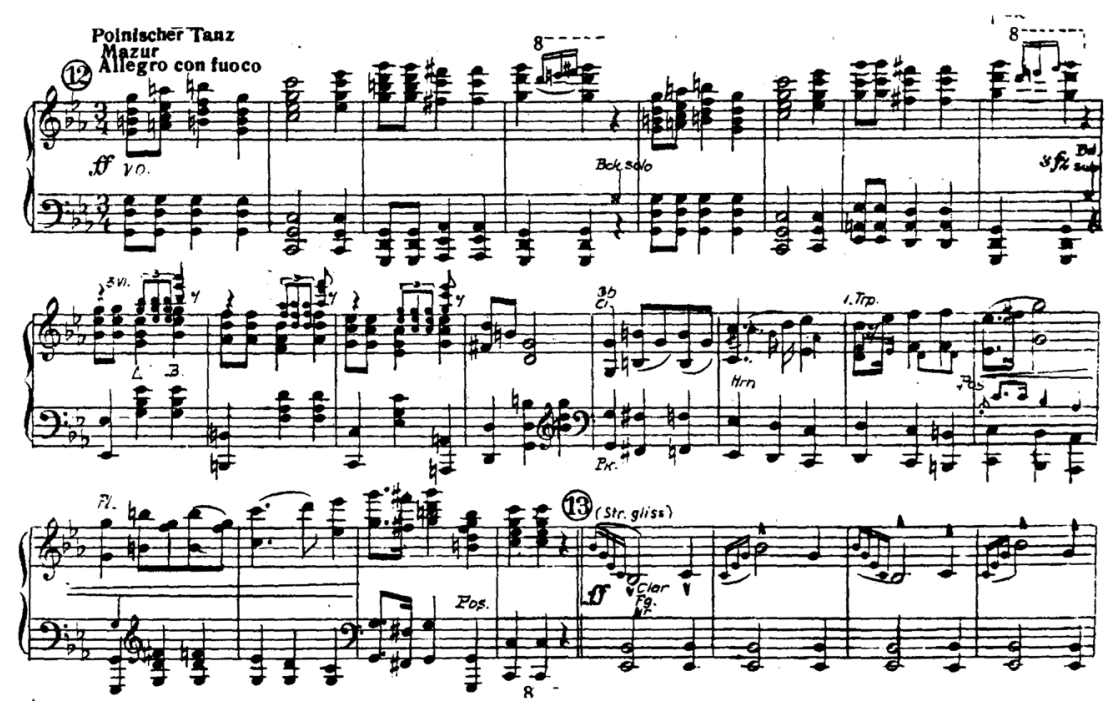

Przykł. 5. Joseph Beer, Polnische Hochzeit, finał II aktu, cytat melodii Umart Maciek, umart ${ }^{24}$.

W operetkach odnaleźć można i inne przejawy stylizacji muzycznych związanych z Polską, wykraczających poza obiegowe cytowanie rytmiki polskich tańców narodowych. Imitacja instrumentów orkiestry wiejskiej zaznacza się tak w duecie Es bläst ein Trompeter z Polnische Wirtschaft, jak i w scenie dożynek w Polenblut (Marsch der Dorfmusikanten). W tej scenie dożynek występuje także podniosła modlitwa ludu, zwracającego się do Boga o błogosławieństwo dla Polski, zakończona powtarzaną aklamacją „Amen”. Sugestywne odwzorowanie ludowej religijności wydaje się bardzo celnym sposobem przedstawienia społeczeństwa polskiego, dalekim od obiegowych rozwiązań dramaturgicznych. Ale jednocześnie taki sposób kreacji polskiego środowiska mógł stanowić element politycznie zapalny w sytuacji zaborów, zarówno w kręgu rosyjskim, jak i austriackim, niechętnie widziany przez władze obu krajów zaborczych ${ }^{25}$.

Problematyka badawcza związana z mechanizmami kreowania stereotypów narodowych w ramach kultury mieszczańskiej wydaje się zagadnieniem ze wszech miar istotnym dla zrozumienia współczesnych sposobów postrzegania jednych narodów przez inne. Odwieczne kontakty Polaków z Niemcami, Austriakami i Rosjanami pozwoliły na wzajemne poznanie się tych nacji, ale rozmaite doświadczenia

24 Polnische Hochzeit. Operette in 3 Akten u. einem Vorspiel von Alfred Grünwald und Fritz Löhner-Beda, Musik von Joseph Beer [wyciąg fortepianowy], Wien 1937 Wiener Operetten-Verlag, s. IO3.

25 Otto Schneidereit, Operette A-Z: Ein Streifzug durch die Welt der Operette und des Musicals, Berlin I98I, s. $246-247$. 
historyczne zadecydowały o powstaniu różnych uprzedzeń i uproszczeń. W tym trwającym od wieków procesie komunikacji i kulturowego dyskursu szczególne miejsce przypada fenomenowi niemieckojęzycznej operetki, będącej czułym barometrem nastrojów społecznych. Żywotność operetki jako gatunku artystycznego wynikała w okresie jej świetności z roli rejestrującej i dokumentującej, co miało szczególne znaczenie w czasach, w których dopiero powstawały nowoczesne media masowej komunikacji. Omówione dzieła sceniczne, powstałe w momencie historycznej zmiany związanej z odradzaniem się niepodległej Polski, wydają się świetnymi argumentami w dyskusji o znaczeniu owych stereotypów w komunikowaniu się sąsiadujących ze sobą nacji.

\section{POLISH ISSUES IN TWENTIETH-CENTURY GERMAN OPERETTA}

Operetta played a major role in bourgeois culture of the late nineteenth and early twentieth centuries, as it developed and promoted national and local self-identification and awareness. Berlin and Vienna became the main centres of German-language operetta - a genre marked by the strong presence of characters and motifs associated with national and ethnic identities. Among the wealth of German operettas composed up to the outbreak of the Second World War, an important place is occupied by works referring to Polish subjects in their plots or featuring Polish characters. The predominant way of presenting Poles in operettas was to compare them with representatives of German (or Austrian) society.

The end of the First World War was a watershed for the Polish nation, as the country regained its independence in 1918. It might be assumed that this would alter the way Poles were depicted in German operetta of the post-war period. The proposed comparison of a few pre-war German operettas with Polish themes (Polnische Wirtschaft, 1909; Polenblut, 1913) with post-war works (Die blaue Mazur, 1920; Der letzte Walzer, 1920; Die polnische Hochzeit, 1937) will help to determine whether and how the political changes brought about by the First World War were reflected in the plots, characters and music of German operetta of the interwar period.

These issues are important to our comprehension of how some nations are perceived by others still today. The vitality of operetta as an artistic genre during its heyday stemmed from its documental role, particularly significant before the emergence of modern mass media. The discussed theatrical works, written at the moment of historical change associated with the revival of independent Poland, provide excellent arguments in debate on the impact of these stereotypes on communication between neighbouring nations.

\section{Ryszard Daniel Golianek}

Słowa kluczowe / keywords: operetka niemiecka / German operetta, tematy polskie / Polish themes, XX wiek / 2oth century, stereotypy narodowe / national stereotypes. 
Prof. dr hab. Ryszard Daniel Golianek pracuje na Uniwersytecie im. Adama Mickiewicza w Poznaniu i w Akademii Muzycznej im. Grażyny i Kiejstuta Bacewiczów w Łodzi. Głównym zakresem jego zainteresowań badawczych jest historia i estetyka muzyki, głównie XIX wieku.

Opublikował m.in.: Dramaturgia kwartetów smyczkowych Dymitra Szostakowicza (1995); Muzyka programowa XIX wieku. Idea i interpretacja (1998); Juliusz Zarębski. Cztowiek, muzyka, kultura (2004); Zrozumieć operę (2009); Przewodnik po muzyce Mahlera (2012); Opery Józefa Michata Ksawerego Poniatowskiego (2012); Polska w muzycznej Europie. Tematyka polska $w$ dzietach kompozytorów zagranicznych XIX wieku (2019).

degol@amu.edu.pl

\section{Archiwalne zeszyty „Muzyki”}

mmn.ispan.pl/pl/wydawnictwa/ crasopisma

iswydawnictwo@ispan.pl

\section{Publikacja projektu HERA „Sound Memories”}

The polyphonic hymns of Valentin Triller's

Ein Schlesich singebüchlein (Wrocław 1555)

edited by Antonio Chemotti

zamówienia:iswydawnictwo@ispan.pl

www.soundme.eu

\section{Nowa seria wydawnicza Instytutu Sztuki PAN „Muzyka polska za granicą"}

\section{Tom 1: Twórcy-źródła-archiwa}

red. Beata Bolestawska-Lewandowska i Jolanta Guzy-Pasiak 